there should be quinquennial reviews of the work of the research councils by ad hoc committees of the Council on Science and Technology, with public reports to Parliament. One practical difficulty here, of course, is that no British minister, especially if he has a seat in the cabinet, will agree that reports from advisory committees should be published as of right. The chances are that what emerged would be as anodyne and as self-congratulatory as are the annual reports of the research councils at present. After all, it is remarkable but not surprising that in the whole argument about Rothschild, nobody has mentioned that the origin of the row lies in the poor organization of the Agricultural Research Council, now apparently openly acknowledged. If the committee really wants periodic reviews of the research councils' work, and that would be proper, why does it not resolve to undertake them on its own account?

The chief merit of the Rothschild recipe is that it would have put responsibility for a good deal of basic research in Britain where it properly belongs, in the government departments. And the truth is that under the British constitution, ministers in charge of government departments are at present accountable to Parliament not merely for their obvious executive functions but for their use of scientific research or, more commonly, for its neglect. One of the defects of the research council system is that is has allowed government departments to shelter behind the research councils. Especially if contracts let under the customer-contractor principle were published, it would at least be possible for government departments to be saddled with responsibility for what they do or neglect to do. If, in the process, they were compelled to equip themselves with competent scientific advice, that would be an extra benefit.

\section{Housing Policy Muddle}

THE British Government seems bent on perpetuating the muddle over housing policy which has bedevilled British housing policy for decades. Mr Peter Walker, one of the most pliable of ministers, responded last week to the complaints which there have been about the housing shortage with the announcement that an extra $£ 80$ million would be made available to local authorities for the purchase of land on which to build dwellings of all kinds. The immediate consequence will no doubt be that there will be far more outlets for the funds which the building societies have to spend. More agricultural land will disappear under concrete and bricks. The urban and suburban sprawl will spread still further. And then, perhaps even next year, money will be hard to come by again, the building societies will become reluctant lenders, and the housing market will embark on yet another of its periodic cycles of boom and bust. Especially now that Mr Walker prides himself on the title of Secretary of State for the Environment, and boasts of the way in which his post allows him to superintend the fashioning of the face of Britain as a whole, it would have been better if he had stood back a little from the problem and asked what the long-term objectives of housing policy should be.

The first thing to be said is that the present imbalance between the demand for housing and the supply could in principle be met in other ways than by increasing the supply. Few people will deny that the British people are badly housed, but the present boom in the mortgage market is a flash in the pan. There might have been something to be said, on this occasion, for an attempt to redress the balance by making it harder for building societies to be easy lenders. Especially because $\mathrm{Mr}$ Walker's first claim on public and political attention stemmed from his success as a financial wizard, it is a surprise that he has apparently neglected this possibility.

The Department of the Environment should also have paid some attention to the question of where all the new houses will be built. Over the years, British governments have by all appearances been dedicated to the view that cities are unpleasant places. As a result, they have done their best to spread the bricks and concrete over the face of England and even of the Celtic fringe. The result is that even though close on a half of the population of the United Kingdom lives south-east of the infamous line from the Solent to the Wash, and does so by inclination, London is distinguished among metropolitan cities by its emptiness.

What is needed in Britain now is a resolution by the metropolitan authorities that the time has come for a radical revision of their previous creed of dispersion, and a recognition that it should be possible somehow to combine a policy for the improvement of the cities with a self-denying ordinance on the further exploitation of good agricultural land. In short, what Mr Walker should have decided is that the time has come when the great cities of the United Kingdom should have their arms twisted to agree that they and not the suburbs must grow. The objective should be to provide the British people with the best of all three accessible worlds-the improvement of the cities, the preservation of the countryside and the housing of the people.

\section{Yeurs Ago}

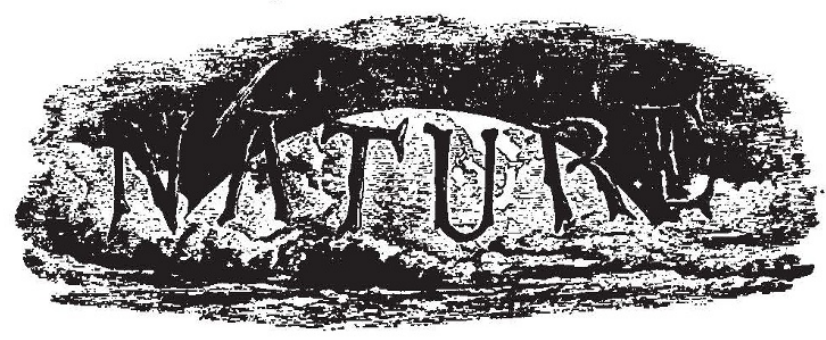

AT the meeting of the Royal Geograpisical Suciety held on Monday evening last, Sir Henry Rawlinson said that the opinion of the Council of the Society was favourable to the authenticity of the inteliigence received by telegram respecting Dr. Livingstone. They had every reason to expect that Dr. Livingstone and Mr. Stanley would meet about the beginning of the year. But if there had been any discovery and relief, it was Dr. Living. stone that had discovered and relievel $\mathrm{Mr}$. Stanley, and not Mr. Stanley who had discovered and relieved Dr. Livingstone; because Dr. Livingstone was in clover an $1 \mathrm{Mr}$. Stanley was ab. solutely destitute. They knew by the last account that Mr. Stanley was without supplies, and he must have undergone much difficulty in getting to Ujiji; whereas this place was the head-quarters of Dr. Livingstone's supplies. He expected that they would have full letters in the course of a fortnight from Zanzibar, which would inform them on what was known about Dr. Livingstone and Mr. Stanley, and in the meantime he could only say that the telegram was credible.

From Nature, 6, 51, May 161872. 